\title{
Comparação entre duas técnicas de descongelamento de sêmen equino baseada na motilidade e vigor espermático
}

Victor Hugo Fernandes ${ }^{[a]}$, Liédge Camila Felicio ${ }^{[a]}$, Luciano Cordeiro Xavier ${ }^{[a]}$, Gabriel Barcellos Felicio ${ }^{[b]}$, João Filipi Pereira ${ }^{[a]}$, Luiz Ernandes Kozicki[c] Ivens Navarro Haponiuk Prusic]

\footnotetext{
[a] Universidade Tuiuti do Paraná (UTP), Curitiba, PR, Brasil

${ }^{[b]}$ Médico veterinário doutor em reprodução, Campos do Jordão, SP, Brasil

[c] Pontifícia Universidade Católica do Paraná (PUCPR), Curitiba, PR, Brasil
}

*Autor correspondente

e-mail: victofernandes@hotmail.com

\section{Resumo}

A criopreservação do sêmen equino tem grande importância no melhoramento genético da espécie, porquanto possibilita a maximização do uso de reprodutores melhoradores. Porém, o principal entrave para a utilização do sêmen criopreservado está relacionado com significativa variação entre indivíduos relacionada às habilidades de os espermatozóides sobreviverem ao processo da criopreservação e na viabilidade espermática após o descongelamento. Os parâmetros de temperatura ideais no momento do descongelamento do sêmen refletem-se como uma variável primordial para a obtenção de uma maior taxa de eficiência reprodutiva. 0 presente estudo teve por objetivo avaliar duas técnicas de descongelamento de sêmen equino em diferentes tempos e temperaturas, considerando-se os parâmetros de motilidade e vigor espermático pós-descongelamento. A pesquisa foi realizada com seis garanhões de diferentes raças, sendo três Brasileiros de Hipismo, dois Puro Sangue Inglês e um Puro Sangue Árabe, na região metropolitana de Curitiba e interior do Estado de São Paulo. Foram descongeladas duas palhetas de sêmen de cada reprodutor sob diferentes temperaturas e avaliados os parâmetros espermáticos de motilidade e vigor do ejaculado. Os parâmetros foram avaliados subjetivamente em microscópio ótico em lâmina/lamínula, por profissional experiente. Foram constituídos dois grupos: Grupo46 (descongelamento à temperatura de $46^{\circ} \mathrm{C}$ por 20 segundos), resultando em 60\% de motilidade espermática e vigor 3; e Grupo37 (descongelamento à $37^{\circ} \mathrm{C}$ por 30 segundos), perfazendo a média de $58,0 \%$ de motilidade e 3 de vigor espermático. Não houve diferença $(\mathrm{P}>0,05)$ entre os grupos. Ambos os grupos atingiram as expectativas da qualidade do sêmen pós-descongelamento consistente com os parâmetros propostos (Manual, CBRA, 1998). 0 padrão dos parâmetros espermáticos após o descongelamento sofre forte variação entre indivíduos. A variação inclui 
a partida de sêmen congelado e a temperatura utilizada ao descongelamento. Isto advém muitas vezes de fatores individuais, acarretando redução ou aumento da taxa de fertilidade, características que envolvem o processo de descongelamento (danos causados às estruturas das membranas celulares, por exemplo). Concluiu-se que ambos os métodos de descongelamento equino mostraram-se eficientes nas características propostas no estudo.

Palavras-chave: Parâmetros espermáticos. Descongelamento. Sêmen. 